\title{
Benzene Exposure on Rig $X$ from Drilling Fluid and Effectiveness of Local Exhaust Ventilation
}

\author{
Paparan Benzene pada Rig X dari Drilling Fluid dan Keefektifan Local Exhaust \\ Ventilation
}

\author{
William, Sjahrul Meizar Nasri \\ Department of Occupational Health and Safety, Faculty of Public Health, Universitas Indonesia \\ Building C, 1 st Floor Faculty of Public Health Universitas Indonesia, Depok, West Java 16424, Indonesia
}

\begin{abstract}
Introduction: Benzene is a carcinogenic compound commonly found in drilling fluid, a chemical used in oil and gas drilling operations. Benzene exposure to workers is known to cause acute and/or chronic disease. Adequate control measures shall be identified and implemented to prevent the adverse health effects of benzene from the utilization of drilling fluid. Methods: This study measured benzene concentrations at several locations, above the drilling rig, which has the potential risk of benzene vapor exposure. From the measurement results, if the threshold limit value was exceeded, LEV was proposed to be installed and the effectiveness of LEV at each location would be assessed. A two-tailed t-test was used with a confidence level of $95 \%(\alpha=0.05)$ to measure the effectiveness of LEV. Results: In several areas, benzene concentration exceeded TLV-TWA, and LEV was installed in those areas as control measures. In this study, it was found that LEV was not always effective in reducing the concentration of benzene in some areas. Conclusion: Drilling fluid was essential for drilling activity, and this could cause benzene vapor to contaminate the working area. The installation of the LEV shall consider the type of containment through which the drilling fluid flows to ensure the mitigation measures are effective to reduce the concentration of benzene in the air that may be exposed to workers.
\end{abstract}

Keywords: benzene, drilling fluid, exhaust ventilation

\section{ABSTRAK}

Pendahuluan: Benzene adalah senyawa karsinogenik yang biasa ditemukan dalam drilling fluid, bahan kimia yang digunakan dalam operasi pengeboran minyak dan gas. Paparan Benzene terhadap pekerja diketahui dapat menyebabkan penyakit akut dan/atau kronis. Langkah-langkah pengendalian harus diidentifikasi dan diterapkan untuk mencegah dampak buruk kesehatan dari benzena dari pemanfaatan cairan pengeboran. Metode: Penelitian ini mengukur konsentrasi benzene di beberapa lokasi, di atas drilling rig yang berpotensi terhadap risiko paparan uap benzene. Dari hasil pengukuran, jika nilai ambang batas terlampaui, LEV disarankan untuk dipasang dan efektivitas LEV di setiap lokasi akan dinilai. t-test two-tailed dilakukan dengan menggunakan tingkat kepercayaan 95\% $(\alpha=0.05)$. Hasil: Di beberapa lokasi pada drilling rig, konsentrasi benzene melampaui TLV-TWA dan LEV dipasang pada lokas-lokasi tersebut sebagai tindakan kontrol. Pada penelitian ini didapatkan bahwa LEV tidak selalu efektif untuk mengurangi konsentrasi benzene di beberapa area. Simpulan: Drilling fluid adalah komponen penting dalam aktifitas pengeboran dan dapat menyebabkan uap benzene mencemari lokasi kerja. Pemasangan LEV harus mempertimbangkan jenis penutup dimana drilling fluid mengalir untuk memastikan tindakan pencegahan dapat berfungsi efektif untuk mengurangi konsentrasi benzene di udara yang dapat memajan pekerja.

Kata kunci: benzene, drilling fluid, ventilasi pembuangan

Corresponding Author:

William

Email: william2110@hotmail.com

Telephone: +628119913442

\section{INTRODUCTION}

Drilling fluid is a crucial element in the drilling process. Drilling fluid, or often referred to as mud, is circulated from the storage or pit, pumped down into the drilled well via the drill string and the drill bit, and returned back to the surface via the annulus (Bridges and Robinson, 2020). The function of drilling fluid is to remove cuttings from the drilled 
hole; suspend and remove cuttings at the surface; give the counter formation pressure to prevent a blowout; seal permeable formations; as well as cool, lubricate, and support the drilling bit and drilling assembly.

Benzene vapor may be found in drilling fluid at a low concentration under normal conditions. Drilling fluid that has gone through circulation from the drilling process will rise in temperature and pressure. This results in changes to its composition or causes a chemical reaction that produces other substances. The heated drilling fluid, from the drilling process, can evaporate a lot of benzene into the air. Benzene is found at various locations on a drilling rig, especially in the drilling fluid preparation and recirculation areas, with concentrations ranging from 1 to $20 \mathrm{ppm}$ (Chan et al., 2020).

Benzene (C6H6) is a colorless, sweet smelling, and highly flammable chemical. Benzene is also categorized as a carcinogenic substance. Benzene exposure to humans is usually related to diseases or health issues, either acute or chronic diseases (US OSHA, 2014; ACGIH, 2021).

Benzene can enter the body through the lungs, digestive tract, and skin. When a person is exposed to certain levels of benzene in the air, the inhaled benzene will pass through the lungs and enter the bloodstream. When a person is exposed to benzene from food, the benzene that is consumed will pass through the digestive tract and enter the bloodstream. Benzene can also enter the body through the skin and into the bloodstream from skin contact with products containing benzene.

Short-term (acute) exposure to high concentrations of benzene can cause shortness of breath, dizziness, nausea, or intoxication. Severe exposure to benzene may lead to convulsions and loss of consciousness. Benzene may also cause skin irritation if the skin is exposed to benzene and may cause eye irritation and cornea damage if the eyes are exposed.

Chronic benzene exposure could lead to various blood disorders, such as anemia and acute myeloid leukemia, (Barton, 2014; US OSHA, 2014; Bassig et al., 2015; Febyan, Linardi, and Hudyono., 2015). Several blood disorders associated with benzene exposure may occur without symptoms. Occupational benzene exposure also increases the risk of cancer, such as colorectal cancer (Talibov et al., 2018).

The use of the drilling fluid will require a specific health risk assessment because the risk of toxic exposure to workers can be quite high if not properly identified and evaluated. Therefore, the necessary control measure shall be developed to reduce the risk. Traces of benzene can be found in the area where the drilling fluid is treated. (Daae et $a l ., 2019)$. Drilling fluid exposed areas are generally open areas, such as flowlines and mud pits. The heated drilling fluid will evaporate diesel material, with a by-product in the form of benzene (Chan et al., 2020).

Mechanical ventilation is an effective choice for reducing VOC concentrations in an enclosed area. Local exhaust ventilation is one of the main engineering controls to reduce the concentration of toxic contaminants in the air (Flynn and Susi, 2012; Hasan, Said and Leman, 2012; Mallach et al., 2017; Sekar, Varghese and Ravi Varma, 2019).

This study aims to determine the exposure to benzene from the use of drilling fluid in the work site during the drilling operation and determine the effectiveness of local exhaust ventilation in reducing benzene exposure to workers on the drilling rig.

\section{METHODS}

The method of measurement carried out in this study was grab sampling. Grab sampling was done by measuring the benzene concentration at a distance of $50 \mathrm{~cm}$ from the source and the breathing zone, as a representative area where the air was inhaled by workers. The sampling was done with a duration of between 45-60 seconds for each point of measurements.

The grab sampling tool used for measurements was RAE Systems UltraRAE 3000 Photoionization Detector (PID), which could measure benzene concentrations above $50 \mathrm{ppb}$. This equipment used a Photo Ionization Detector (PID) sensor. The equipment had been calibrated and tested by a thirdparty certification body at yearly intervals to ensure its measurement accuracy.

The first measurement was performed at locations which had a potential of benzene vapor exposure from the drilling fluid to the area, while workers might access and work in the specified area. The main areas of drilling fluid exposure were the active pit, reserve pit, flowline to the mud pit, possum belly, drill floor, and shale shaker (BroniBediako and Amorin, 2010; Daae et al., 2019). These locations were selected for initial measurement. The initial measurement was done on 31 October 2019.

After obtaining the results from the initial measurement, places with exposure to benzene concentrations above the Threshold Limit Value- 
Time Weighted Average (TLV-TWA) were proposed to be installed with Local Exhaust Ventilation (LEV) to reduce the concentration of benzene in the area and reduce the exposure to the workers. The followup measurements were done on 10-12 December 2019, 19-21 February 2020, and 8-9 March 2020 to measure the effectiveness of the LEVs installed at locations where benzene concentration was above the worker exposure limit from the result of the initial measurement.

Threshold Limit Value - Time Weighted Average (TLV-TWA) is the level of concentration to which a worker can be exposed day after day during the working period without adverse effects. This level of concentration is averaged over an 8-hour workday and a 40 -hour workweek. Another value to be considered is the Threshold Limit Value - Short Time Exposure Limit (TLV-STEL), which is a 15minute time-weighted average exposure that should not be exceeded at any time during a workday. Workers should not be exposed to concentrations between TLV-STEL and TLV-TWA more than four times a day, and there should be at least a 60-minute interval between exposures (ACGIH, 2021).

Based on ATSDR and NIOSH, Benzene TLVTWA for an 8-hour work schedule per day is 1 ppm (National Institute for Occupational Safety and Health, 2014). Based on the Indonesian Government Regulation regarding the operation of the company and ACGIH, the TLV for the normal work schedule is $0.5 \mathrm{ppm}$ (Minister of Health of the Republic of Indonesia, 2016; ACGIH, 2021). A more stringent approach was applied, and $0.5 \mathrm{ppm}$ was used as the value for TLV-TWA in this study.

The adjustment of TLV for work shifts of more than 8 hours per day and 40 hours per week can be done using the adjusted NAV model from Brief and Scala (Brief and Scala, 1975; ACGIH, 2021), which calculates the TLV proportionally by calculating the work shift and rest periods. The adjusted TLV formula with Scala, where $\mathrm{h}$ is the working shift duration.

$$
\text { Adjusted TWA }=\operatorname{TLV} \times \frac{8 \text { hours }}{\mathrm{h}} \times \frac{(24-\mathrm{h})}{16}
$$

Company Y implements a shift work system with a duration of 12 hours for each shift. With the Brief and Scala Model, the Adjustment Threshold Limit Value for workers with a 12-hour work shift and results in $0.25 \mathrm{ppm}$, which will be used as the Adjusted TLV-TWA in this study.

$$
\text { Adjusted TWA }=0.5 \mathrm{ppm} \times \frac{8 \text { hours }}{12 \text { hours }} \times \frac{12}{16}
$$

TLV-STEL of benzene from NIOSH is $5 \mathrm{ppm}$ (National Institute for Occupational Safety and Health, 2014). Based on the Indonesian Government Regulation, the TLV-STEL is $2.5 \mathrm{ppm}$ (Minister of Health of the Republic of Indonesia 2016). As the local regulation was more stringent, $2.5 \mathrm{ppm}$ was used as the value for TLV-STEL for assessment in this study.

Follow-up measurements were carried out after the installation of LEV. The measurements would compare the concentration of benzene, at the source and breathing zone area, before and after the LEV was turned on, to obtain the data and analyze the effectiveness of the LEV to reduce benzene concentrations in the area. The two-tailed test would be used for statistical evaluation with a confidence level of $95 \%(\alpha=0.05)$ to measure the effectiveness of LEV.

This study has passed the ethical test conducted by The Research and Community Engagement Ethical Committee of the Faculty of Public Health Universitas Indonesia with ethical certificate Number Ket- 611/UN2.F10.D11/PPM.00.02/2020.

\section{RESULTS}

Initial measurements were done on rig $\mathrm{X}$ during the delivery of the drilling service operation at company Y on 31 October 2019 in East Borneo. The initial measurement at the Active Pit, Reserve Pit, Flowline, Possum Belly, Shale Shaker, and Rig Floor produced results summarized in Table 1.

From the initial measurement, it was evaluated that flowline and possum belly area had benzene concentration above the Adjusted TLV-TWA $(0.25 \mathrm{ppm})$ and below TLV-STEL $(2.5 \mathrm{ppm})$ in the breathing zone area. Workers entering these areas were mandatory to wear respiratory protective equipment, such as a gas mask, which could reduce the benzene concentration entering their respiratory tract and, eventually, could reduce the cancer risk (Tunsaringkarn et al., 2012; Gjesteland et al., 2018). Administrative controls, such as minimizing exposure duration and work schedules, had to be applied when workers entered the area.

From the measurement, it was also found that benzene concentrations at the active pit and reserve pit area was above TLV-STEL (2.5 ppm). Workers were prohibited to enter these areas if they were 
not wearing proper respiratory protection, such as positive pressure or airline or self-contained breathing apparatus.

LEVs were proposed to be installed at the active pit, flow line, and possum belly. This proposal was accepted by the Rig's company, and the effectiveness of the LEVs would be checked and analyzed in the follow-up measurements after the LEVs were provided, and installation was completed.

Follow-up measurements were performed after the LEV had been installed. These follow-up measurements were carried out in three measurement periods. The follow-up measurements were carried out on 10-12 December 2019, 19-21 February 2020, and 8-9 March 2020, consecutively.

The results of the follow-up measurements at the active pit area, flowline, and possum belly when the LEV was turned off and turned on at the source can be seen in Table 2. The results of follow-up measurements at the active pit area, flowline, and

Table 1. Benzene Concentration Measurement at the Source and Breathing Zone

\begin{tabular}{lcccccc}
\hline & \multicolumn{6}{c}{ Measurement in ppm } \\
\cline { 2 - 7 } Area & \multicolumn{3}{c}{ Source } & \multicolumn{5}{c}{ Breathing Zone } \\
\cline { 2 - 7 } & Mean & Max & n & Mean & Max & n \\
\hline $\begin{array}{l}\text { Active } \\
\text { Pit }\end{array}$ & 56.77 & 104.80 & 4 & 9.54 & 17.52 & 3 \\
$\begin{array}{l}\text { Reserve } \\
\text { Pit }\end{array}$ & 35.38 & 50.78 & 2 & 10.99 & 17.75 & 2 \\
$\begin{array}{l}\text { Flow } \\
\text { Line }\end{array}$ & 3.66 & 8.95 & 3 & 0.51 & 1.23 & 3 \\
$\begin{array}{l}\text { Possum } \\
\text { Belly }\end{array}$ & 3.11 & 3.65 & 2 & 0.57 & 1.58 & 5 \\
$\begin{array}{l}\text { Shale } \\
\text { Shaker }\end{array}$ & 0.05 & 0.15 & 10 & 0.08 & 0.43 & 15 \\
$\begin{array}{l}\text { Rig } \\
\text { Floor }\end{array}$ & 0.17 & 0.17 & 1 & 0 & 0 & 1 \\
\hline
\end{tabular}

Table 2. Results of Benzene Concentration and the Comparison when LEV was Turned On and Turned Off at the Source

\begin{tabular}{ccccc}
\hline \multirow{2}{*}{ Area } & LEV & \multicolumn{3}{c}{$\begin{array}{c}\text { Measurement at the Source } \\
\text { in ppm }\end{array}$} \\
\cline { 3 - 5 } & & Mean & $\mathbf{n}$ & p-value \\
\hline \multirow{2}{*}{ Active Pit } & Off & 1.006 & 30 & 0.0006 \\
& On & 0.093 & 30 & \\
Flowline below & Off & 1.871 & 12 & 0.3674 \\
the rig floor & On & 1.507 & 12 & \\
\multirow{2}{*}{ Possum Belly } & Off & 0.969 & 15 & 0.8341 \\
& On & 1.013 & 15 & \\
\hline
\end{tabular}

possum belly when the LEV was turned off and turned on at the source can be seen in Table 3 .

From the result of follow-up measurements, the use of LEV in the active pit could significantly reduce the benzene concentration, both at the source and the breathing zone, with $\mathrm{p}<0.05$, accounting for 0.0006 and 0.0348 , respectively.

The use of LEV in the flowline has not been proven to significantly reduce the concentration of benzene at the source and breathing zone. This can be seen with a value of $p>0.05$, accounting for 0.3674 and 0.1029 , respectively in the source and breathing zone.

The use of LEV on the possum belly has not been proven to significantly reduce the concentration of benzene at the source and breathing zone. This can be seen with a value of $p>0.05$, accounting for

Table 3. Results of Benzene Concentration and the Comparison when LEV was Turned On and Turned Off at the Breathing Zone

\begin{tabular}{ccccc}
\hline \multirow{2}{*}{ Area } & LEV & \multicolumn{2}{c}{$\begin{array}{c}\text { Measurement } \\
\text { Breathing Zone in ppm }\end{array}$} \\
\cline { 3 - 5 } & & Mean & $\mathbf{n}$ & p-value \\
\hline \multirow{2}{*}{ Active Pit } & Off & 0.266 & 30 & 0.0348 \\
& On & 0.008 & 30 & \\
Flowline below & Off & 0.513 & 12 & 0.1029 \\
the rig floor & On & 0.268 & 12 & \\
\multirow{2}{*}{ Possum Belly } & Off & 0.278 & 15 & 0.1015 \\
& On & 0.218 & 15 & \\
\hline
\end{tabular}

Table 4. Results of Benzene Concentration from Follow-Up Measurements on the Rig Working Area where LEV was not Installed

\begin{tabular}{|c|c|c|c|c|c|c|}
\hline \multirow{3}{*}{ Area } & \multicolumn{6}{|c|}{ Measurement in ppm } \\
\hline & \multicolumn{3}{|c|}{ Source } & \multicolumn{3}{|c|}{ Breathing Zone } \\
\hline & Mean & Max & $\mathbf{n}$ & Mean & Max & n \\
\hline $\begin{array}{l}\text { Flowline to } \\
\text { the Mud Pit }\end{array}$ & 1.18 & 6.36 & 36 & 0.00 & 0 & 36 \\
\hline $\begin{array}{l}\text { Shale } \\
\text { Shaker }\end{array}$ & 0.51 & 2.16 & 45 & 0.26 & 4.74 & 45 \\
\hline Reserve Pit & 0.32 & 1.83 & 36 & 0.01 & 0.15 & 36 \\
\hline $\begin{array}{l}\text { Mud Logger } \\
\text { Cabin }\end{array}$ & 0.02 & 0.22 & 36 & 0.01 & 0.3 & 36 \\
\hline Mud Lab & 0.00 & 0 & 27 & 0.00 & 0 & 27 \\
\hline $\begin{array}{l}\text { Driller } \\
\text { Cabin }\end{array}$ & 0.00 & 0 & 27 & 0.00 & 0 & 27 \\
\hline Rig Floor & 0.00 & 0 & 18 & 0.00 & 0 & 18 \\
\hline $\begin{array}{l}\text { Cutting } \\
\text { Barge }\end{array}$ & 0.00 & 0 & 18 & 0.00 & 0 & 18 \\
\hline
\end{tabular}


0.8341 and 0.1015 , respectively in the source and breathing zone.

During follow-up measurements, there were opportunities to perform measurements in remaining working area on the rig. The results of follow-up measurements at the remaining working area on the rig can be seen in Table 4 .

Based on the measurements at the source, the average benzene concentration at the flowline below the rig floor, possum belly, flowline to the mud pit, shale shaker, and reserve pit was above the adjusted TLV-TWA. Meanwhile, the benzene concentration at the active pit, mud logger cabin, mud lab, driller cabin, rig floor, and the cutting barge was below the adjusted TLV-TWA.

Based on the results of the measurements at the breathing zone, the average benzene concentration at the flowline below the rig floor and shale shaker was above the adjusted TLV-TWA. Meanwhile, benzene concentration at the active pit, possum belly, flowline to mud pit, reserve pit, mud logger cabin, mud lab, driller cabin, rig floor, and the cutting barge was below TLV-TWA.

\section{DISCUSSION}

Based on the initial measurement with the grab sampling method, benzene concentrations were found to exceed TLV-TWA in the active pit, flowline, and possum belly. This confirms that the drilling fluid can produce benzene from evaporated material in the drilling fluid (Chan et al., 2020). This indicates a potential risk of benzene exposure in the area, and therefore further assessment considering the exposure time of workers in the area should be conducted to have the actual benzene exposure risk to personnel.

From the measurement results, it was found that at the mud lab and mud logger cabin, benzene concentrations were below the TLV-TWA, even though the areas had a high risk of benzene exposure due to the amount of drilling fluid in the areas. This was caused by the usage of LEVs in the mud lab room and mud logger cabin, as there had been a prior precaution by the rig's company based on their previous assessment, and this action could reduce or even remove benzene vapor in an enclosed room (Mallach et al., 2017).

Benzene concentrations from follow-up measurements at the active pit, reserve pit, flowline, and possum belly were lower than the benzene concentrations from the initial measurement, even

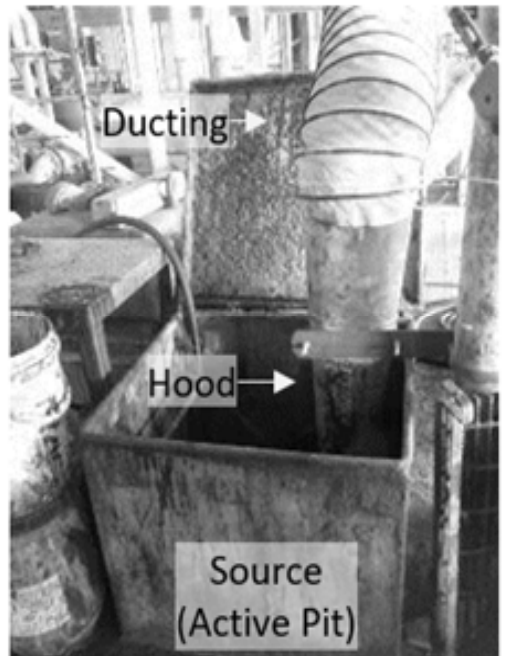

Figure 1. LEV Position at the Active Pit

before LEV was turned on. From the assessment, it was found that the drilling operation in the followup measurements used reconditioned drilling fluid. In the initial measurement, a new drilling fluid was used, and this might result in a higher benzene concentration in the air. A further study can be done for this issue to get a more comprehensive result of benzene concentration with new drilling fluid, and prevention measures may be required to be implemented if this issue is confirmed in the next study.

From this study, it is concluded that the installation of LEV could reduce benzene concentration in the active pit area. The benzene concentration decreased and reached a concentration below the TLV-TWA in the breathing zone. In the active pit, LEV was proven effective to reduce the concentration of benzene significantly. This could occur because the active pit is an enclosed containment system that only has one opening hole for observation, and LEV is installed in the opening hole. The position of LEV at the active pit can be seen in Figure 1.

Additional safety precautions shall be prepared when the installed LEV may not be operated at the active pit, i.e., from break-down or maintenance since it may cause the benzene concentration to be above TLV-TWA. Moreover, workers in the area are required to implement safety measures such as limiting work duration and using proper respiratory protective equipment (IPIECA, 2009).

The installation of LEV in the flowline and possum belly was not proven to significantly reduce benzene concentration in the area. This could be caused by drilling fluid in the flowline area and the 


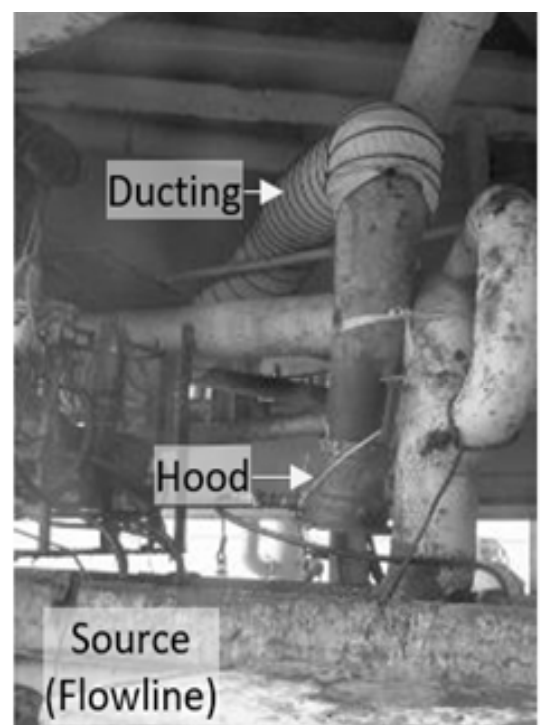

Figure 2. LEV Position at the Flowline Area

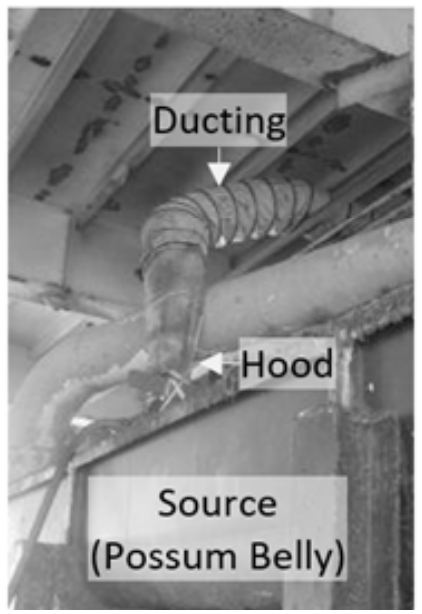

Figure 3. LEV Position at the Possum Belly

possum belly which was not in an enclosed system, such as the active pit, and therefore the LEV was not effective for these areas. The position of LEV at the flowline area and possum belly can be seen in Figure 2 and Figure 3.

Upgrading the drilling circulation system with an enclosure to ensure an acceptable working environment may be effective to reduce benzene concentration in the air (IPIECA, 2009; BroniBediako and Amorin, 2010). Even so, this method may be a problem for old rigs since there will be limited space, and any structural change will require major refurbishment and cost.

Non-occupation exposure to benzene, such as smoking habit which is a common activity in the rig, is an aggravating factor of benzene risk to workers (Carrieri et al., 2018). A change in smoking habits to a healthy lifestyle can also reduce the risk of benzene effects to health.

Food intake with high CYP2E1 enzyme, such as from cow liver, cow brain, and salmon, may help detoxification of benzene inhaled by the workers (Tualeka et al., 2020). Workers are expected to consume higher intake of CYP2E1 enzyme if they are exposed to higher concentration of benzene with longer duration.

\section{CONCLUSION}

Drilling fluid is essential for drilling activity, and this may result in benzene vapor contaminating the working area. An assessment shall be conducted to determine applicable mitigation measures, such as the utilization of LEV and/or blower to introduce air circulation and fresh air. The installation of LEV need to consider the type of containment where the drilling fluid is flowing; this is done to ensure that the mitigation measure is effective to reduce the concentration of benzene in the air that may be exposed to the workers. If the utilization of LEV is not effective or considered ineffective, other mitigation measures need to be implemented. Using respiratory protection equipment, such as using a gas mask or breathing apparatus depending on the measured concentration at the work location, and administrative control, such as minimizing workers' duration in the benzene-exposed area, may reduce the amount of benzene inhaled and reduce the risk of benzene exposure to the workers.

\section{ACKNOWLEDGEMENTS}

I want to give great gratitude to my family and friends who have given their support for the accomplishment of this research.

\section{REFERENCES}

ACGIH (2021) 2021 TLVs and BEIs. Cincinnati: American Conference of Governmental Industrial Hygienists.

Barton, C. (2014) 'Benzene', in Encyclopedia of Toxicology. Elsevier, pp. 415-418.

Bassig, B. A. et al. (2015) 'Occupational Exposure to Benzene and Non-Hodgkin Lymphoma in a Population-based Cohort: The Shanghai Women's Health Study', Environmental Health Perspectives, 123(10), pp. 971-977. 
Bridges, S. and Robinson, L. (2020) A Practical Handbook for Drilling Fluids Processing. Elsevier: Gulf Professional Publishing.

Brief, R. S. and Scala, R. A. (1975) 'Occupational Exposure Limits For Novel Work Schedules', American Industrial Hygiene Association Journal, 36(6), pp. 467-469.

Broni-Bediako, E. and Amorin, R. (2010) 'Effects of Drilling Fluid Exposure to Oil and Gas Workers Presented with Major Areas of Exposure and Exposure Indicators', Research Journal of Applied Sciences, Engineering and Technology, 2(8), pp. 710-719.

Carrieri, M. et al. (2018) 'Biological Monitoring of Low Level Exposure to Benzene in an Oil Refinery: Effect of Modulating Factors', Toxicology Letters, 298(July), pp. 70-75.

Chan, L. et al. (2020) 'Drilling Fluids: Presence of Hazardous Btexs and Crystalline Silica', Journal of Environmental Treatment Techniques, 8(3), pp. 1029-1035.

Daae, H. L. et al. (2019) 'Occupational Exposure during Treatment of Offshore Drilling Waste and Characterization of Microbiological Diversity', Science of the Total Environment, 681, pp. 533-540.

Febyan, A. W., Linardi, M., and Hudyono, J. (2015) 'Pengaruh Pajanan Benzena terhadap Timbulnya Leukemia Mieloid Akut pada Pekerja yang Terpajan', Buletin Asosiasi Fakultas Kedokteran Swasta Indonesia (AFKSI), (May), pp. 1-14.

Flynn, M. R. and Susi, P. (2012) 'Local Exhaust Ventilation for the Control of Welding Fumes in the Construction Industry-A Literature Review', The Annals of Occupational Hygiene, 56(7), pp. 764-776.

Gjesteland, I. et al. (2018) 'Biomonitoring of Benzene and Effect of Wearing Respirators during an Oil Spill Field Trial at Sea', Annals of Work Exposures and Health, 62(8), pp. 1033-1039.

Hasan, N. H., Said, M. R. and Leman, A. M. (2012) 'Local Exhaust Ventilation and Application: A
Review', International Journal of Engineering \& Technology, 12(4), pp. 39-43.

IPIECA (2009) 'Drilling fluids and health risk management'.

Mallach, G. et al. (2017) 'Exhaust Ventilation in Attached Garages Improves Residential Indoor Air Quality', Indoor Air, 27(2), pp. 487-499.

Minister of Health of the Republic of Indonesia, (2016) Peraturan Menteri Kesehatan Nomor 70 Tahun 2016 tentang Standar dan Persyaratan Kesehatan Lingkungan Kerja Industri. Jakarta: Minister of Health of the Republic of Indonesia,

National Institute for Occupational Safety and Health (2014) 'CDC - Immediately Dangerous to Life or Health Concentrations (IDLH): Benzene - NIOSH Publications and Products', NIOSH.

Sekar, A., Varghese, G. K. and Ravi Varma, M. K. (2019) 'Analysis of Benzene Air Quality Standards, Monitoring Methods and Concentrations in Indoor and Outdoor Environment', Heliyon, 5(11), pp. 1-15

Talibov, M. et al. (2018) 'Benzene Exposure at Workplace and Risk of Colorectal Cancer in Four Nordic Countries', Cancer Epidemiology, 55(January), pp. 156-161.

Tualeka, A. R. et al. (2020) 'Prediction of The Needs for Benzene Detox with Foods Intake Containing CYP2E1 Enzyme, Sulfation, and Glutathione at Gas Stations Pancoranmas Depok, Indonesia', Indian Journal of Forensic Medicine \& Toxicology, 14(1), pp. 118-123.

Tunsaringkarn, T. et al. (2012) 'Cancer Risk Analysis of Benzene, Formaldehyde and Acetaldehyde on Sasoline Station Workers', Journal of Environmental Engineering and Ecological Science, 1(1), p. 1-6.

US OSHA (2014) 'Safety and Health Topics Benzene', Safety and Health Topics. 